\section{Joseph Priestley}

Adventurer in Science and Champion of Truth. By F. W. Gibbs. (British Men of Science.) Pp. xii $+258+$ 20 plates. (London and Edinburgh: Thomas Nelson and Sons, Ltd., 1965.) 42s. net.

JOSEPH PRIESTLEY is a scholarly and readable account of this remarkable Englishman, the dissenting minister and teacher whose experimental discoveries immediately speeded up the progress of science, but whose advanced political views were widely accepted only a generation after his death.

Priestley did not contribute to science until 1765 , when at thirty-two he began to compile his history of electricity. He soon turned to chemistry and started to work on gases in the winter of 1767-68, five years before the publication of his first great paper on "Different Kinds of Air". The important chemical work of the 1770's and early 1780's is well described by Dr. Gibbs, who clearly shows how Priestley was repeatedly forced to grapple with unfamiliar and difficult problems arising from his discovery and examination of a dozen new gases. Priestley quickly contrived methods for saturating mineral waters with carbon dioxide, and for generating hydrogen on a large scale in order to fill balloons.

Not only was he a great chemist but Priestley was also an accomplished linguist and biblical scholar. The book throws new light on his persecution for supporting the French revolution and his subsequent exile in America.

Dr. Gribbs has not only given an account of Priestley's life and work based on a very thorough study of printed and manuscript sources, but he has also described the political, religious, social and scientific background in both England and America. The many illustrations, including a number of political cartoons of the period, add to the value of a book which supersedes the earlier biographies of Priestley and can be recommended to all scientists interested in their intellectual ancestor.

\section{W. A. Smeaton}

\section{The Evolution of the Nuclear Atom}

By G. K. T. Conn and H. D. Turner. Pp. $266+$ 13 plates. (London: Iliffe Books, Ltd.; New York: American Elsevier Publishing Company, Inc., 1965.) 55s. net.

7 HIS is the first of four volumes attempting to show the development of modern ideas on molecular, atomic and nuclear structure. It ranges from Faraday's first studies on electrical discharges in gases up to the Rutherford-Bohr theory of 1913-14. About 90-95 per cent of the material consists of original papers or excerpts from original papers by the principal figures of the time. Most of the quoted passages are from the decisive work of such people as Crookes, Thomson, Rydberg, Geiger, Marsden, Rutherford, Moseley, Chadwick and Bohr, but there are also a number of excerpts on some of the less successful ideas, such as Hertz's view that the cathode rays were a form of radiation, and there is a chapter on the more abortive theories of atomie structure proposed by Jeans, Thomson, Nagaoka, Rayleigh and Schott. These various passages are linked by a sketchy narrative in which the authors have made little attempt at com. mentary. Their intention has been to let the original authors speak for themselves.

The stated aim of the book is to "provide a stimulus to young research workers", but it is difficult to imagine this being its effect. Young research workers are not likely to read it. It cannot be denied that the momentous papers of Thomson, Rutherford, Bohr and the others make powerful reading even half a century later, yet their collective effect in this presentation is just not inspiring. This sort of material requires much more in the way of historiography to make it interesting.

W. M. CURRIE
Atomic Handbook

Vol. 1: Europe. Edited by John W. Shortall. Pp. xvi+ 845. (London: Morgan Brothers (Publishers), Ltd., 1965.) 140s.; 20 dollars.

rHIS publication represents the fruitful result of several years discussion both within and without the Nuclear Public Relations Contact Group. Information on what is going on in atomic physics is invariably the most difficult to obtain, and Mr. Shortall, as editor, and Morgan Brothers (Publishers), Ltd., have done signal service in providing all concerned with atomic physics with Atomic Handbook Volume 1: Europe.

The directory has been designed to give answer to who is doing what and where in atomic energy. It is elaimed that it has been written "to sorve as a management tool to locate collaborators, follow trends, prevent waste of resources and to facilitate interchange and cortact". Essentially, then, it is a guide to people and their work. It provides an invaluable source of names, positions, addresses and telephone numbers of key people concerned with the day-to-day business of atomic energy. This first volume includes details of some 4,000 people in twenty. six countries, eighteen international organizations and almost a thousand industrial firms.

It is pleasing to note that the Atomic Handbook will be revised at least every 2 years and also that it is intended shortly to produce successive volumes covering other areas of the world. We all wish the enterprise well, and humbly thank all concerned for taking on the herculean task of making European atomic physics accessible.

\section{Plant and Machinery for the Separation of Air by Low Temperature Methods}

Design Atlas. By I. P. Usyukin, I. G. Aver'yanov, S. Gorokhov, A. M. Gorshkov, A. V. Zakharov and N. K. Yelukhin. Edited by I. P. Usyukin. Translated by S. S. Akerib and A. D. Norris. Translation edited by M. Ruhemann. Pp. viii $+185+164$ plates. (London and New York: Pergamon Press, 1965.) 250s. net.

N this Design Atlas, 171 of the 185 pages (each 18.5 $\times 12.5$ in. in size) are devoted to flow diagrams of air separation plants, plant layouts or detailed drawings of equipment for use in such plants. Although mainly concerned with designs of Russian plants and equipment, some information about plants designed in western Europe and the United States is included.

The Atlas is attractively produced and the drawings are clearly presented. The publishers have ensured the technical accuracy of the work by securing the services of Dr. M. Ruhemann as editor. While the price seems high it is understandably so in view of the work involved in preparation and reproduction.

The foreword to the Russian edition says that the Atlas is designed as a text-book for higher technical institutions and will also be used by staff working in establishments which use low-temperature air separation plants. While this may be true in Russia, one doubts whether either of these groups will find the book useful in western countries. To start with, while in Russia air separation experts are trained as such at undergraduate level, in the West we tend to train men in broader fields and let them specialize later. Furthermore, any leading cryogenic engineering company tends to tailor its plants to suit customer requirements and to incorporate new ideas and items of equipment as they mature. Since this is probably also true of the Russian Oxygen Design Bureau, it is unlikely that the Atlas contains the very latest Russian designs. Certainly the non-Russian designs given are far from being "the most important now existing" as claimed in the foreword; they are inevitably far from comprehensive or up to date.

The cost of producing a gas from the atmosphere is dependent almost entirely on power consumption and capital outlay. Frequently the potential customer has to 